\title{
Temel Motivasyon Kaynakları, Hedef Türleri ve Bağlanma Stilleri Işığında Girişimcilik ${ }^{1}$ (Araştırma Makalesi)
}

Entrepreneurship in the Light of Basic Motivation Sources, Types of Goals and Attachment Styles

Doi: 10.29023/alanyaakademik.805024

\section{Ömer Lütfi ANTALYALI}

Doç. Dr., Süleyman Demirel Üniversitesi İletişim Fakültesi Halkla İlişkiler ve Tanıtım Bölümü omerantalyali@sdu.edu.tr Orcid No: 0000-0002-9600-9581

\author{
Ahmet Sait ÖZKUL \\ Doç. Dr., Süleyman Demirel Üniversitesi İletişim Fakültesi Halkla İlişkiler ve Tanıtım \\ Bölümü \\ saitozkul@sdu.edu.tr \\ Orcid No: 0000-0001-8858-4685
}

Hüseyin ŞATIRER

Ögrr. Gör., Süleyman Demirel Üniversitesi Isparta Sağllk Hizmetleri Meslek Yüksekokulu, Tıbbi Hizmetler ve Teknikler Bölümü

huseyinsatirer@sdu.edu.tr

Orcid No: 0000-0003-1334-4403

Bu makaleye atıfta bulunmak için: Antalyall, Ö. L., Özkul, A. S. \& Şatırer, H. (2021). Temel Motivasyon Kaynakları, Hedef Türleri ve Bağlanma Stilleri Işı̆̆ında Girişimcilik. Alanya Akademik Bakış, 5(1), Sayfa No.21-43.

Anahtar kelimeler:

Çalışma Dĕ̆erleri

Başarı Ihtiyacı

Güç İhtiyacı

Bağlanma Stilleri

Girişimci Adayı

Makale Geliş Tarihi:

04.10.2020

Kabul Tarihi:

12.12.2020

\section{ÖZET}

Bu çalışmada girişimcilik eğitimi alan bireylerin çalışma değerleri; temel motivasyon kaynaklart, hedef türleri ve bağlanma stilleri bağlamında incelemektedir. Çalışmayla, literatüre katkı sağlamanın yanında girişimci adaylarına, kamu ve özel sektör karar vericilerine farklı bir bakış açısı kazandırılması amaçlanmaktadır. Çalışmanın odak noktasını başarı ve güç motivasyonuna sahip girişimci adayı bireylerin, çalışma değerlerinin hangi yönde gelişme gösterdiğinin tespiti oluşturmaktadır. Çalışmanın analizleri KOSGEB tarafindan verilen 32 saatlik girişimcilik eğitimini alan 73 girişimci adayının yanıtları kullanılarak gerçekleştirilmiştir. İçsel hedefli olan girişimci adaylarında başarı motivasyonunun çalışma değerlerinin normatif boyutunu pozitif etkilediği, dişsal hedefli girişimci adaylarında ise böyle bir etkinin bulunmadı̆̆ sonucuna ulaşılmıştır. Bununla beraber

\footnotetext{
${ }^{1}$ Bu çalışma, Süleyman Demirel Üniversitesi Sosyal ve Beşeri Bilimler Etik Kurulu Başkanlığı'nın 22.04.2020 tarih ve 90/10 sayılı kararınca "Etik Kurul Onayı" alınarak ve katılımcılara araştırma hakkında gerekli bilgilendirmeler yapılarak tamamlanmıştır.
} 
korkulu bağlanma düzeyi düşük olan girişimci adaylarında güç motivasyonunun çalışma değerlerinin normatif boyutunu pozitif etkilediği, adayların korkulu bağlanma düzeyi yükseldikçe bu etkinin kaybolduğu ortaya konulmuştur.

\section{Keywords:}

Work Values

Need for Success

Need for Power

Attachment Styles

Entrepreneur

Candidate

\begin{abstract}
This study examines the working values of individuals - who receive entrepreneurship education - within the context of basic motivation sources, types of goals and attachment styles. The study, besides contributing to the literature, aims to provide entrepreneur candidates, decision-makers in the public and private sectors with a different perspective. The focus of the study is to determine the direction in which the working values of entrepreneurial candidates who have success and power motivation are developing. The analysis of the study was carried out using the responses of 73 entrepreneurial candidates who received a 32-hour training course on entrepreneurship from KOSGEB. It was concluded that the motivation for success positively influences the normative dimension of the work values in entrepreneur candidates with intrinsic goals, whereas there is no such effect in externally oriented entrepreneur candidates. However, it was found that power motivation positively influences the normative dimension of work values in entrepreneurial candidates with a low degree of anxious attachment, and this effect disappears as the degree of anxious attachment of the candidates increases.
\end{abstract}

\section{GİRIŞ}

Başarılı girişimciler bilim dünyasında ilgi çekmektedir. Bu alanda yapılan erken dönem araştırmalara göre girişimcileri diğer insanlardan ayıran özellikler kendine güven, çalışkanlık ve başarıdır (Bull ve Willard, 1993: 186). Kimi çalışmalara göre ise yenilikçi ve özgün girişimcilerin topluluğa meydan okumaları ve ortalamadan farklı olmaları beklense de bu farklılıklarının doğasının öngörülebilmesi zordur. Dolayısıyla tipik girişimci profilini tespit etmeye çalışmak boş bir çabadan ibarettir (Low ve MacMillan, 1988: 148). Her ne kadar literatürde tipik bir girişimci profili olamayacağı düşüncesi ortaya atılsa da toplumun girişimciliğe olan ilgisi, ekonomik hayatı iyileştiren yeni olasılıkları teşvik etmektedir. Girişimci özelliklerini anlamak için ise psikoloji önemli bir araştırma alanıdır. Girişimciliği ekonomik değişkenler odağında açıklamaya çalışan araştırmaların girişimcinin motivasyon yoğunluğunu değerlendirme dışı tutarak varsayımda bulunmaları, davranışsal değişkenlerin önemli olduğunu göstermektedir (Bull ve Willard, 1993: 187). Çünkü pek çok girişimci olumsuzluklara veya finansal başarısızlıklarına rağmen bağımsız olarak kariyerleri boyunca çalışmayı arzulamaktadır. Girişimcilerin çalışma anlayışları, "başarılı sonuçların nasıl algılandığı", "motivasyon", "hedefe yönelik davranış" gibi farklı kavramlarla açıklanması nedeniyle dikkat çekicidir. Girişimcileri motive eden etkenleri anlamanın, tüm girişimcilik sürecini anlamak açısından son derece kritik olduğunu söylemek mümkündür. Girişimcilerin; "başarı ihtiyacını karşılama yoluyla özgürlük kazanma", "kendi patronu olma" ve "kendi geleceğini kontrol etme" gibi motive edici unsurlardan etkilendiği görülmektedir. Bağımsızlık, zenginlik ve firsat arayan bireyler de girişimcileri harekete geçiren unsurlardandır. Ayrıca bağlılık, azim, başarı ve fırsat eğilimi özellikleri, girişimcilerin pozitif yönde motive olmalarını sağlamaktadır (Kuratko, 1997: 24-25). 
Girişimcilerin motivasyon ve hedefleri kadar hangi çalışma değerlerine sahip oldukları da önemlidir. $\mathrm{Bu}$ nedenle girişimcilerin sahip oldukları değerlerin tespit edilmesine katkı sağlayacak değişkenler üzerinde durmak gerekmektedir. Literatürde girişimcilik sürecindeki bireylerin ortaya bir değer koymaya çalıştıkları veya bir değerin peşinde oldukları görülmektedir. Bu değer, bazen bir ekonomik kazanç bazen de başarı elde etmek şekline bürünebilmektedir. İş yaşamında aktör olacak girişimci adaylarının çalışma olgusuna dair amaçları ve anlamlandırma süreçleri, onların çalışma değerlerini oluşturmaktadır.

Çalışma değerleri literatürde; bireysel, dünyevi ve normatif çalışma değerleri olmak üzere üç boyut altında toplanmıştır (Tevrüz vd., 2010). Bu çalışmanın odağında girişimci adaylarının normatif çalışma değerleri bulunmaktadır. Çalışmanın normatif işlevinin "toplum tarafından önemsenen" ve "topluma katkı sağlayan" yönünün bir girişimci adayında bulunması önemli kabul edilmiştir. Çalışmada KOSGEB bünyesinde girişimcilik eğitimi alan girişimci adaylarının, hedef türleri ve bağlanma stillerinin etkisiyle ne tür çalışma değeri üretebilecekleri incelenmektedir. Çalışmanın teorik çerçevesi kapsamında öncelikle temel motivasyon kaynakları, içsel/dışsal hedefli oluş, yetişkin bağlanma stilleri ve çalışma değerleri ile ilgili literatür sunulmaktadır. Daha sonra belirtilen konular ekseninde ölçme araçlarıyla gerçekleştirilen araştırma bölümünün bulguları aktarılmaktadır.

\section{TEMEL MOTIVASYON KAYNAKLARI}

İhtiyaçlar ve davranış arasındaki ilişki, McClelland tarafından 1940'lı yılların sonunda incelenmeye başlamıştır. Önceki yönetim araştırmalarında ihtiyaç kuramları ele alındığında, her bireyin ihtiyaçlarının benzer özelliklere sahip olduğu ileri sürülmekteydi. McClelland ise bireyler arası farklılıklara odaklanarak teorisini ortaya koymuştur (Antalyalı ve Bolat, 2017: 4). Çalışan davranışlarının kilit faktörlerini; bireylerin başarı, bağlanma ve güç ihtiyaçlarıyla açıklamıştır. McClelland teorisine "öğrenilmiş ihtiyaçlar" adını vermiştir, çünkü bireyin ihtiyaçlarıyla doğmadığını, hayatını yaşamaya devam ettikçe ihtiyaçlar edineceğini veya öğreneceğini ifade etmiştir (Kinicki ve Futage, 2018: 165).

Temel motivasyon kaynaklarına yönelik araştırmalarda, diğer motivasyon kaynaklarına kıyasla başarı ihtiyacına daha çok odaklanılmaktadır (Robbins ve Judge, 2017: 10). Başarı ihtiyacı, belli standartlarda başarma, başarılı olma çabası ve üstün olma motivasyonunu ifade etmektedir (Langton ve Robbins, 2006: 110). Aynı zamanda bireyin engelleri aşma, sorunları çözme, rakiplerini aşma ve başkalarını aşma isteğidir (Kinicki ve Futage, 2018: 166). Başarı ihtiyacının bilinmesi/tespiti, bireyler ve örgütler için önemlidir. Düşük başarı ihtiyacı olan insanlar, kişisel tatminlerden ziyade kurumdaki gelecekleri ve statüleri ile daha fazla ilgilenirler, kendi fikirleri ve duyguları ile meşgul olurlar. Yüksek başarı ihtiyacı olan insanlar ise aşağıdaki özelliklere sahip olma eğilimindedirler (Huczynski ve Buchanan, 2013: 205):

- Rutin faaliyetlerde bulunmazlar, bunun yerine mükemmel olmak için gereken standartları ve işler tercih ederler.

- Performanslarını görebilecekleri ve daha üst seviyelere taşımak için sık sık geri bildirim aldıkları işleri tercih ederler.

- Yüksek riski olan faaliyetler başarısızlıkla sonuçlanabileceği ihtimaline karşı başarısızlık riski orta düzeyde olan işleri tercih ederler. Aynı zamanda düşük riskli faaliyetleri de yeteneklerini gösterme firsatı sunmayacağı için tercih etmezler.

- Tamamlanmamış işleri sevmezler. Bitmemiş işler için iyi bir hafızaya sahiptirler. 
- Diğerlerinin performanslarını engellemek istemedikleri zaman, içlerine kapanık olurlar ve sosyal ilişkilerini düşük düzeyde tutarlar.

- Her zaman bir aciliyet duygusu içerisinde ve zamana karşı çalışıyor gibi görünürler ve rahatlamaları mümkün değildir.

Güç ihtiyacı, başkalarını etkileyerek belli bir yönde davranış sergilemelerini sağlama motivasyonudur (Robbins ve Judge, 2017: 210). İkna ile sonuçlanacak bir iletişim kurma arzusudur (Antalyalı ve Bolat, 2017: 88). Güç ihtiyacı yüksek olan bireyler diğerleri üzerinde bir etki kurmayı, insanları ve olayları değiştirerek yaşamlarında bir fark oluşturmayı arzularlar (Huczynski ve Buchanan, 2013: 779). Başkalarını kontrol etmek ve onlar üzerinde "sorumlu" olmak isteğindedirler. Statü odaklılık ve rekabetçi olma özelliklerine sahiptirler (Langton ve Robbins, 2006: 109).

Bağlanma ihtiyac1, beğenilme, gruplara katılma ve sosyal ilişkileri sürdürme isteğidir (Kinicki ve Futage, 2918: 166). Diğerleri ile yakın samimi (Robbins ve Judge, 2017: 210) ve arkadaşça ilişki kurma arzusudur (Langton ve Robbins, 2006: 109). Yüksek bağlanma ihtiyac1 olan bireyler arkadaşlıklar için çaba gösterirler, rekabetçi durumlar yerine ortak çalışabilecekleri işleri severler ve yüksek derecede karşılıklı anlayış içeren ilişkileri arzularlar (Langton ve Robbins, 2006: 109).

Temel motivasyon kaynaklarının dördüncüsü ise düşünme ihtiyacıdır. Düşünme ihtiyacı, bireyin düşünmesini/anlamasını gerektiren zorlu bilişsel süreçlerin içerisinde bulunmaktan dolayı keyif almasıdır (Cacioppo ve Petty, 1982: 116-117). Düşünme ihtiyacı yüksek olanlar düşünme eyleminin bizzat kendisinden keyif alır ve düşünme/anlama gerektiren etkinliklerle zaman geçirmek isterler. Düşünme ihtiyacı yüksek olan bireyler herhangi bir gerekçeye bağımlı olmadan düşünme sürecini yaşamaktan dolayı tatmin olurken, düşük olanlar ise çoğunlukla motive edilerek veya bir sebebe bağlı olarak düşünmeyi tercih ederler (Antalyalı ve Bolat, 2017: 89-90).

\subsection{Hedef Türleri}

Girişimcilik süreçlerini anlamak için şu sorulara odaklanılmalıdır: "Bir kişiyi harekete geçiren şey nedir?", "Kişiye bir davranışı diğerine tercih ettiren şey nedir?", "Neden farklı insanlar aynı uyarıcı faktörlere farklı tepkiler vermektedir?”. Bu sorulara verilecek cevaplar, fikirle eylem arasındaki ilişkiyi ortaya çıkarır. Hedefler tam bu noktada bireyin fikri/niyeti ile eylemi arasında önemli bir bağlantı görevi görür ve insanların vazgeçmemelerini sağlar. Çünkü hedefler bireyin gelecekte neler olabileceğine dair sahip olduğu zihinsel temsillerdir. (Aksoy vd., 2019: 113). Bir davranışın, insan faaliyetinin doğasında var olan ilgi, memnuniyet ve haz merkeze alınarak serbest kaldığında içsel hedeflerle şekillenmesi söz konusudur. Karşılığında maddi veya sosyal bir ödül almak amaçlandığında ise davranış, dışsal hedeflerle biçimlenir. Bu durumda faaliyetin amacı faaliyetin kendisi değil, değerli görülen bir sonucunun peşinde olmaktır (Ryan ve Deci, 2000: 70).

Hedefler içeriklerine göre içsel ve dışsal olmak üzere iki tipte sınıflandırılmaktadır. Bireysel gelişim odaklı olma, kişilerarası ilişkilerin iyi olması, topluma katkı sağlama ve fiziksel açıdan sağlıklı oluş içsel hedefler, finansal açıdan varlıklı olma, ünlü olma ve çekici bir görünüme sahip olma ise dişsal hedefler şeklinde nitelenmektedir (Kasser ve Ryan, 1996: 281). İçsel hedefler, bireylerin doğuştan gelen özerklik, ilişki, yeterlilik ve gelişme gibi psikolojik ihtiyaçlarını karşılamaları nedeniyle takip edilmeleri doğal olarak tatmin edici olan 
hedeflerdir. Bireyler bu tür içsel hedefleri takip edip ilerleme kaydettiklerinde, gittikleri yol boyunca ihtiyaçlarını karşılayan ve böylece mutluluklarının ve refahlarının artmasını sağlayan birçok tecrübe elde ederler. Dışsal hedefler ise (örneğin, finansal başarı, çekicilik ve popülerlik) ödüller almaya ve başkalarının olumlu değerlendirmelerine odaklanır. Dışsal hedefler genellikle bireyin kendisiyle ilgili güvensizlik duygusunu yansitır. Ayrıca bireyin ihtiyaçlarını tatmin edemeyen daha stresli, kontrollü ve ego içeren davranışlarda bulunmasına yol açar. $\mathrm{Bu}$ nedenle, bireyler özellikle dışsal hedeflere yöneldiklerinde, ihtiyaçlarını görmezden gelirler ve sağlıklarına ve kendi iyi oluşlarına uygun olmayan faaliyetlerde bulunabilirler (Schmuck vd., 2000: 225-226).

\subsection{Bağlanma Kuramı ve Yetişkin Bağlanma Stilleri}

Bowlby (1973) bağlanma kuramını; insanların yakın ilişkilerinde güçlü duygusal bağlar kurma eğilimlerinin nedenlerini inceleyen bir yaklaşım olarak tanımlamaktadır (Sümer ve Güngör, 1999b: 72). Bağlanma kuramı, bireylerin erken yaşlarda bakımlarını üstlenen kişi/kişilerle (genellikle anne ya da bakıcı) kurdukları ilişkilerin, o bireylerin ilerleyen yaşlarındaki duygu, düşünce ve davranışlarında belirleyici olduğunu ortaya koyar (Selçuk vd., 2005: 2). Bartholomew ve Horowitz (1991) ve Brennan, Clark ve Shaver (1998) dört temel bağlanma stilini kaygı ve kaçınma boyutlarıyla tanımlamışlardır.

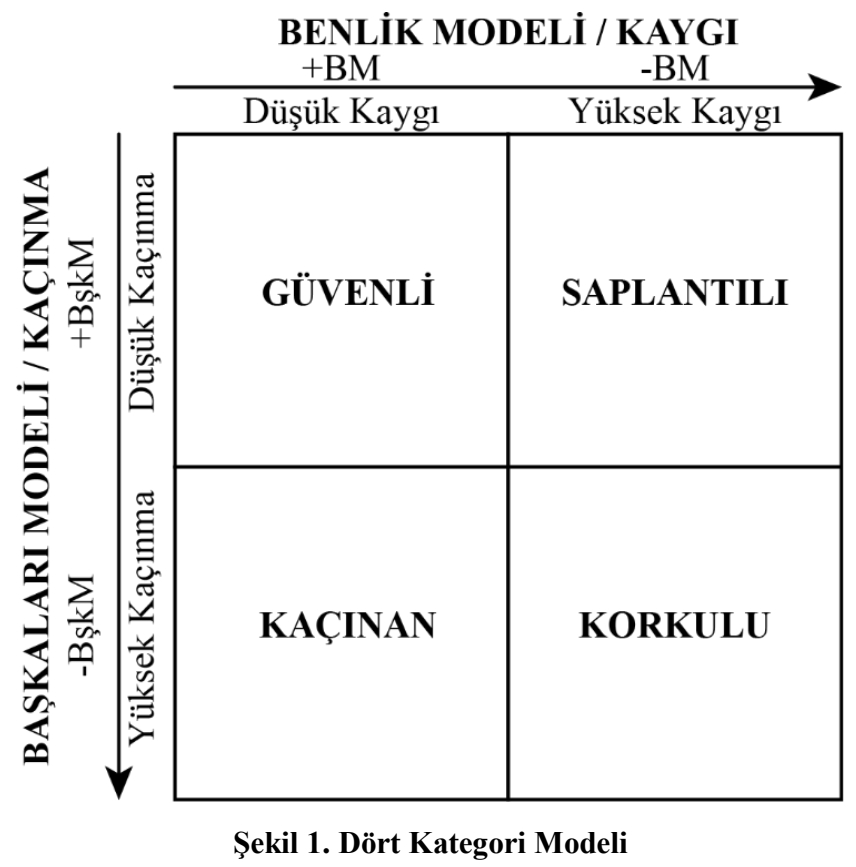

Şekil 1'de; kaygı boyutu ile benlik modeli, kaçınma boyutu ile de başkaları modeli ilişki içinde bulunmakla temel boyutları oluşturduğu görülmektedir. Güvenli bağlanma stili; düşük düzeyde kaygı (olumlu benlik modeli) ile kaçınma (olumlu başkaları modeli) boyutunda tanımlanmaktadır. Bunun zıddında yer alan korkulu bağlanma stili; her iki boyutun da yüksek düzeyleriyle (olumsuz benlik ve olumsuz başkaları) tanımlanmaktadır. Saplantılı bağlanma stili; yüksek kaygı (olumsuz benlik) ve düşük kaçınma (olumlu başkaları) ile 
tanımlanmaktadır. Son olarak kayıtsız bağlanma stili; düşük kaygı (olumlu benlik) ve yüksek kaçınma (olumsuz başkaları) düzeyleriyle tanımlanmaktadır (Sümer, 2006: 2).

Bowlby’ye göre bağlanma, insanın tüm yaşamı süresi boyunca devam eden bir süreçtir. Bununla beraber erken yaşlarda oluşan zihinsel modeller, çok değişime uğramadan yetişkinlikte de işlevini sürdürür (Sümer ve Güngör, 1999a: 38). Hazan ve Shaver (1987), bireylerin çocuk yaşlarda bağlanma figürü ile kurmuş oldukları ilişkinin bir benzerinin yetişkinlikte romantik ilişkiler açısından da geçerli olduğunu belirtmişlerdir. $\mathrm{Bu}$ araştırmacıların çalışmalarıyla bağlanma kuramı, yetişkinlerin duygu, düşünce ve davranışlarını incelemek için kullanılan bir kuram şeklini almıştır (Selçuk vd., 2005: 2). Hazan ve Shaver (1987), Ainsworth, Blehar, Waters ve Wall'ın (1978) çocuklar için yaptıkları sınıflandırmayı yetişkinlere uygulayarak "güvenli-kaygılı/kararsız-kaçınan" stillerin romantik ilişkilerde de ortaya çıktığını ileri sürmüşlerdir. Bu çalışmanın öncülük etmesiyle ise, yetişkin bağlanmasındaki bireysel farklılıkları ve bunların psikolojik sonuçlarını inceleyen çalışmalar ortaya çıkmıştır (Günaydın vd., 2005: 14). Hazan ve Shaver (1990); örgütsel çevrede işler durumda olan bağlanma sistemini, bireysel farklılıklar açısından ele almışlardır. Bu öncü çalışma ile birlikte; işyerindeki performansın çeşitli yönleri ile bağlanma stilleri arasındaki ilişkiler konusunu değerlendirme zemini oluşmuştur. Söz konusu çalışmanın sevkiyle, bağlanma kuramı araştırmacıları da örgütsel süreçlerle artan bir şekilde ilgilenmeye başlamışlardır. Lider ve takipçileri arasında, grup dinamikleri ve ilişkilerdeki duygusal bağlanma şeklinin, kavramsal olarak; çocuk, büyüme çağında veya yetişkin olanların anne babalarıyla, arkadaşlarıyla ve romantik partnerleriyle kurdukları ilişkinin şekliyle benzer olabileceğini belirtmişlerdir (Mikulincer ve Shaver, 2016: 473).

\section{3. ÇALIŞMA DEĞERLERI}

"Çalışma" kavramı, modern toplumlarda yaşayan bireyler için en temel ve önemli faaliyetlerden birisidir. Gelişmiş ülkelerdeki bireylerin yaşamlarında merkezi ve temel bir rol oynamaktadır (Harpaz ve Snir, 2003: 296). İnsan hayatında vazgeçilmez role sahip olan çalışma herkes tarafından farklı algılanabilir. Bireyler çalışmayı; yapılması gereken görev, gelişim gösterilen süreç, yaşamın başlıca amacı, bazen bir tür ceza çekme veya kendilerini ifade etmek için en uygun yol olarak görebilirler (Turgut, 1996: 23). Fakat değişmeyen bir gerçek varsa o da çalışma sürecinin her insan açısından önemli olduğudur. Çünkü bu süreç zarfında bireyler, çalışma değerlerini geliştirirler (İnançoğlu, 2002: 150). Bu süreçte toplum, sosyal çevre, grup ve bireysel özellikler, kişilerin yaşam ve çalışma zihniyetlerini belirleyici rol üstlenir. Nitekim çalışma zihniyeti, bir topluluğun üyelerinin değer, tavır, inanç ve fikirlerinden oluşur. Bu olgular "çalışma değerleri”" olarak kabul edilir. Çalışma değerleri; bir topluluğun veya bireyin çalışma(k) kavramında olmasını istedikleri özellikleri ve çalışmaya yönelik yaklaşımlarını içermektedir (Özkul, 1997: 15).

Çalışma değerleri, bireyin tercihleri ve davranışlarını yönlendiren ihtiyaç, güdü, amaç, ilke ve inanç gibi kavramlarla bağlantılıdır. Bu noktada çalışma değerlerinin; bireyin ihtiyaçları, amaçları, çalışma rolleri ve faaliyetleri açısından harekete geçmesi için güdü kaynağı olduğu ifade edilebilir. Çalışma değerlerinin yapısı genel sınıflandırma bağlamında iç kaynaklı ve dış kaynaklı olmak üzere ikili yapıdadır. Dış kaynaklı değerler; para, maddi mal varlığı, iş güvenliği, tatil olanakları, çalışma şartları veya iyi bir emeklilik planı gibi faaliyetin gerçekleşmesinden sonra elde edilen somut neticelerdir. İç kaynaklı değerler ise faaliyetin kendisinden alınan zevk ve amaca ulaşmaktan kaynak bulur. Bu nedenle iç kaynaklı değerler; ilgi çekici iş, entelektüel uyarılım, buluşçuluk, özerklik veya başkaları üzerinde etkisi olacak 26 
bir şeyleri başarmak gibi çalışma süreciyle ilgili maddi olmayan ödülleri içine alır (Turgut, 2017: 22-23).

Çalışma değerleri, çalışma yoluyla elde edilmesi farklı derecelerde istenen amaçlar olarak ifade edilir. Çalışma değerlerinin 12 maddeden oluşan 3 boyutlu yapısı bulunmaktadır. Çalışmanın Bireyselci Işslevi, bilgi edinmek/kullanmak, sevdiği işi yapmak, hayatına hareket katmak, hayatına anlam vermek, hayatına keyif katmak, kendini meşgul etmek amaçlarını bünyesinde barındıran daha ziyade iç kaynaklı bir yapıyı temsil eder. Bireysel özgünlüğü ve özerkliğe dair amaçlara ulaşma işlevini ifade eder. Çalışmanın Dünyevi İşlevi, geçimini temin etmek ve statü kazanmak amaçlarını bünyesinde barındırarak dünyevi durumlarla ilgili amaçlara ulaşma işlevini temsil eder. Bu işlev diş kaynaklı çalışma değerleriyle benzerlik göstermektedir. Çalışmanın Normatif Işslevi, topluma katkıda bulunmak, sakınmak, dini görevini yapmak, düzenini kurmak amaçlarını bünyesinde barındırarak toplumca önemsenen, norm niteliğindeki amaçlara ulaşma işlevini ifade eder (Tevrüz ve Turgut, 2004; Tevrüz vd., 2010).

\section{GIRIŞSIMCI ADAYI BİREYLERIN TEMEL MOTIVASYON KAYNAKLARI, HEDEF TÜRLERİ VE BAĞLANMA STILLERININ ÇALIŞMA DEĞERLERİ İLE İLIŞKISSININ DEĞERLENDİRILMESI}

Çalışmanın bu bölümünde; araştırma sorusu ve hipotezler, katılımcılar ve prosedür, veri toplama araçları, verilerin analizi ve araştırma bulguları yer almaktadır.

\subsection{Araştırma Sorusu ve Hipotezler}

Girişimcilerin başarılı olmalarında güç ve başarı motivasyonlarının etkili olduğu bilinmektedir. Yani güç motivasyonu ve başarı motivasyonu yüksek girişimcilerin başarılı olma potansiyeli daha yüksektir (Thompson ve Martin, 2005: 458). Peki bu girişimciler hangi çalışma değerlerine sahip olacaktır? Bunu önceden kestirmek mümkün müdür? Bu çalışmada özellikle hangi girişimci adaylarının değer üretmeyi amaç edineceği merak edilmiştir. Çalışma değerleri arasında, "değer üretmek" normatif değerler boyutunun altında incelenmiştir (Tevrüz vd., 2010). Literatürde başarı motivasyonu ile normatif çalışma değerleri arasında herhangi bir ilişkinin gözlemlenmediği (Özkul ve Antalyalı, 2017) veya zayıf bir ilişkinin gözlemlendiği (Özkul vd., 2018) çalışmalara rastlanmaktadır. Bu araştırmalardan yola çıkarak başarı motivasyonuyla normatif çalışma değerleri arasında direkt güçlü bir ilişkinin olmadığı söylenebilir. Güç motivasyonu ile normatif çalışma değerleri arasındaki ilişkinin araştırıldığı bir çalışmaya ise rastlanmamıştır. Mantıksal olarak böyle bir hipotezin kurulması için bir sebep de bulunmamaktadır. $\mathrm{Bu}$ çalışmada başarı ve güç motivasyonlarının temel dinamikleri incelenmiş ve bu motivasyonların normatif çalışma değerleri ile ilişkilerini hangi değişkenlerin düzenleyebileceği üzerinde durulmuştur. Önceki çalışmalarda direkt bir ilişki gözlemlenmemiş olsa da düzenleyici değişkenler eşliğinde ilişkinin olabileceği öngörülmüştür.

Başarı motivasyonunun önemli göstergelerinden bir tanesi hedef odaklılıktır (George vd., 2012: 52). Kimler değer üretmeyi hedefleyecektir? Bireyin hangi hedef türüne sahip olduğuna göre başarı motivasyonunun normatif çalışma değerlerine etkisinin farklılık göstereceği düşünülmüştür. İçsel hedeflere sahip olanlarda başarı motivasyonu normatif çalışma değerlerine pozitif etki ediyor olabilir düşüncesiyle $\mathrm{H}_{1}$ hipotezi kurulmuştur: 
$\mathrm{H}_{1}$ : "Girişimci adaylarının başarı motivasyonlarının normatif çalışma değerlerine etkisini hedef türleri düzenler."

Güç motivasyonunun önemli göstergelerinden bir tanesi başkaları üzerinde duygusal ve davranışsal güçlü bir etki oluşturma arzusudur (Winter, 1973: 301). Bu etki kimlerde değer üretme şeklinde olabilir? Özellikle bireyin olumsuz bir çevre ve olumsuz bir benlik algısı varsa güç motivasyonunun böyle bir fayda üretmeyi tetikleyeceği düşünülemez. Halihazırda birey ne kendine ne çevresine yeterince değer vermiyordur. Dolayısıyla korkulu bağlanan bireylerin güç motivasyonlarının normatif çalışma değerlerine etki etmeyeceği, korkulu bağlanma düzeyi düşük olanlarda ise böyle bir etkinin olabileceği düşünülmüştür ve $\mathrm{H}_{2}$ hipotezi kurulmuştur.

$\mathrm{H}_{2}$ : "Girişimci adaylarının güç motivasyonlarının normatif çalışma değerlerine etkisini korkulu bağlanma düzenler."

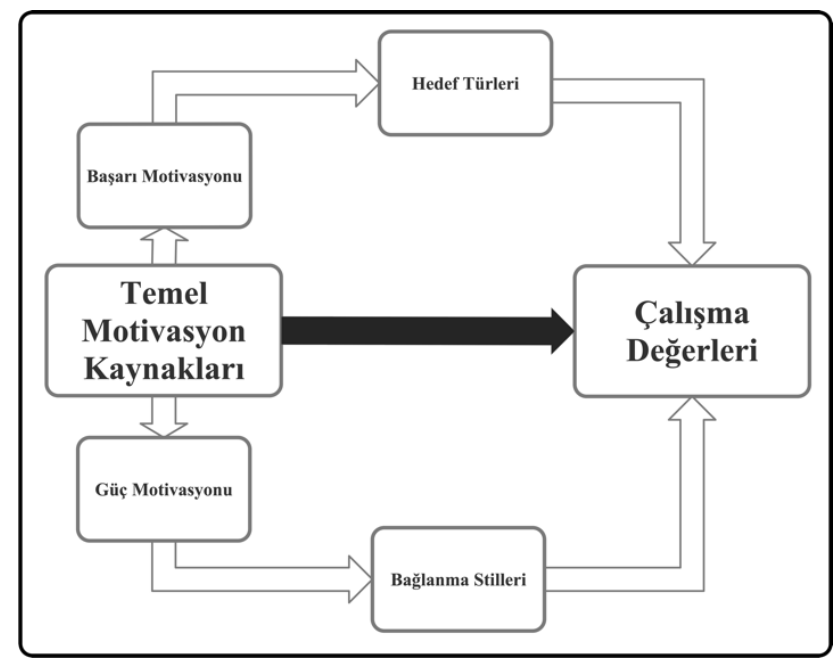

Şekil 2. Araştırma Modeli

Çalışmanın odağı, temel motivasyon kaynakları, hedef türleri ve bağlanma stilleri 1şı̆̆ında girişimci adayı bireylerin çalışma değerlerini tespit etmek üzerinedir. Bu amaçla tasarlanan araştırma modeli Şekil 2'de gösterilmektedir.

\subsection{Katılımcılar ve Prosedür}

Türkiye'de çalışma yaşamının gelişmesi açısından KOSGEB'in girişimcilik eğitimlerinin koordinasyonunu üstlenen önemli bir kurum olması örneklem tercihinde etkili olmuştur. Türkiye'nin geneline yayılmış olan KOSGEB girişimcilik eğitimi alan bireyler evrenini temsil eden araştırmanın örneklemi; Isparta il merkezinde 2017 ve 2018 yılları içerisinde farklı tarih aralıklarında 32 saatlik KOSGEB girişimcilik eğitimi alan 4 gruptan oluşmaktadır. $\mathrm{Bu}$ aynı zamanda araştırmanın sınırlılığıdır. Her bir grupta eğitim hakkı kazanan 25 kişi bulunmaktadır. Araştırmanın verileri, söz konusu gruplarda girişimcilik eğitimi alarak "girişimcilik belgesi”" almaya hak kazanan 91 katılımcıdan eğitim bitiminde elden dağıtılan ve sonrasında toplanan anket formları aracılığıyla elde edilmiştir. Anket içerisine 2 adet kontrol sorusu eklenmiştir. Anketin başlarında yer alan bir sorunun birebir aynısı anketin sonlarında 
tekrar sorulmuştur. Ayrıca yine anketin başlarında yer alan bir sorunun birebir tersi anketin sonlarında tekrar sorulmuştur. Birebir ters sorulan kontrol sorusuna verilen yanıtlar ters kodlanmıştır. Her iki soruda da aralarında 3 'ten büyük fark olan yanıtlar tespit edilmiş ve bu katılımcıların verileri niteliksiz kabul edilmiştir. Neticede 18 katılımcının verileri analiz aşamasında elenmiştir. Analizler 73 katılımcının verileri ile gerçekleştirilmiştir.

Analizlere dahil edilen katılımcıların \%37,5'i kadın, \%62,5'i erkektir. \%33,9'u 20-25 yaş arası, \%36,6'sı 26-30 yaş arası, \%29,5'i 31-54 yaş arasıdır. \%49,3'ü evli, \%50,7'si bekardır. \%30,1'i çocuk sahibi, \%69,9'u çocuk sahibi değildir. \%8,5'i ilkokul, \%12,7'si lise, \%31'i yüksekokul, \%43,7'si üniversite, \%4,2'si yüksek lisans mezunudur. \%37,7'sinin daha önce girişimcilik tecrübesi varken \%62,3’ünün ise herhangi bir girişimcilik tecrübesi yoktur.

\subsection{Veri Toplama Araçları}

Bu araştırmada kullanılan ölçeklerin tamamında 7'li Likert yanıtlama seçeneği kullanılmıştır. Kullanılan ölçeklerin kaynakları ve güvenilirlik bulguları şu şekildedir.

Çalışma amaçları ölçeği: Çalışma amaçları ölçeğini (ÇLMÇ) öncelikle Tevrüz ve Turgut (2004) geliştirmiştir. Tevrüz vd. (2010) ise ölçeğin kısa formunu hazırlamıştır. Anket 12 madde ve 3 boyuttan oluşmaktadır. Normatif değerler boyutunu 3 madde, bireysel değerler boyutunu 6 madde, dünyevi değerler boyutunu ise 2 madde ölçmektedir. $\mathrm{Bu}$ çalışmada güvenilirlik için hesaplanan Cronbach alfa katsayıları normatif değerler için 0,607 , bireysel değerler için 0,646, dünyevi değerler için ise 0,615'tir.

İlişkiler ölçeği: İlişskiler ölçeği Griffin ve Bartholomew (1994) tarafından geliştirilmiştir. Sümer ve Güngör (1999b) ölçeği Türkçeye uyarlamıştır. 17 madde olarak uyarlanmış ölçek güvenli bağlanma, kayıtsız bağlanma, saplantılı bağlanma ve korkulu bağlanma boyutlarından oluşmaktadır. Boyutların iç tutarlılık katsayıları 0,27 ila 0,61 arasında değişmektedir. Boyutların iç tutarlılık katsayılarının düşük olması her bir boyutta ortagonal iki boyut (kaygı ve kaçınma) birleştiği için normal karşılanmıştır (Griffin ve Bartholomew 1994). Carver (1997) ise bu izahı yeterli bulmamış ve itiraz etmiştir. Bu çalışmada bahsi geçen tartışmaya girmemek ve araştırma hipotezlerinin oluşturulmasında yeterli olduğu için araştırma kapsamında sadece iç tutarlılığı yüksek olan "korkulu bağlanma" boyutunun maddeleri kullanılmıştır. Korkulu bağlanma olumsuz çevre ve olumsuz benlik algısının birleştiği bağlanma türüdür (Sümer ve Güngör, 1999b). 4 maddeden oluşmaktadır. Bu çalışmada Cronbach alfa katsayısı 0,678 olarak hesaplanmıştır.

Temel motivasyon kaynakları ölçeği: Temel motivasyon kaynakları (TMK) ölçeği Antalyalı ve Bolat (2017) tarafindan geliştirilmiştir. Ölçeğin kuramsal temeli öğrenilmiş ihtiyaçlara dayanmaktadır. Ölçek Türkiye'deki araştırmalarda kullanılmak üzere kültüre uyumlu olarak geliştirilmiştir. Güç motivasyonu, başarı motivasyonu, düşünme motivasyonu ve bağlanma motivasyonu boyutlarından oluşmaktadır. Bu araştırmanın hipotezleri çerçevesinde ölçeğin güç motivasyonu ve başarı motivasyonu maddeleri kullanılmıştır. Her bir boyutta 6'şar madde mevcuttur. $\mathrm{Bu}$ çalışmada güç motivasyonu maddelerinden 2'si (orijinal ölçekte güç motivasyonunu ölçen son iki madde) iç tutarlılığ düşürdüğü için analiz sürecinde kapsam diş1 bırakılmıştır. Son haliyle Cronbach alfa katsayıları güç motivasyonu için 0,764, başarı motivasyonu için 0,725 olarak hesaplanmıştır.

Hedef türleri: Girişimcilik eğitimi alan bireylerin hedef türlerinin tespit edilebilmesi için anket formunda kendilerine "açık uçlu" iki soru yöneltilmiştir. Sorulardan biri "Sizi girişimci 
olmaya iten gerçek sebep nedir?"; diğeri ise "Sizce girişimciliğin en güzel tarafı nedir?" şeklindedir. Girişimci adaylarının bu soruların her ikisine verdikleri cevaplar doğrultusunda hangi tür motivasyonla (içsel veya dışsal hedefli olma) çalışma hayatında yer almaya eğilimli oldukları anlaşılmaya çalışılmıştır. Bu noktada öncelikli olarak içsel/dışsal hedefli bireylerin özelliklerini ortaya koyan literatürden (Kasser ve Ryan, 1996; Ryan ve Deci, 2000; Schmuck vd., 2000) yararlanılmıştır. Girişimci adaylarının içsel veya dişsal hedefli oluşlarını tespit etmek amacıyla ilgili literatür doğrultusunda belirlenen özellikler, ölçüt yapılmıştır. Girişimci adaylarının açık uçlu sorulara verdikleri cevaplar bu ölçüt baz alınarak değerlendirilmiştir. Hangi tür hedef odaklı oldukları tespit edilen her bir girişimci adayı; içsel hedefli veya dişsal hedefli şeklinde kodlanarak araştırmanın analizine dahil edilmiştir.

\subsection{Veri Analizi}

Verilerin analizinde SPSS paket programı kullanılmıştır. Düzenleyici etki analizlerinde ise Hayes'in (2013) SPSS ve SAS programlarına makro olarak geliştirdiği ve geniş kapsamlı açıkladığı, arka planda en küçük kareler yöntemine dayalı regresyon hesaplamaları ile çalışan PROCESS kullanılmıştır. Düzenleyici etki analizlerinde etki büyüklüğü değerlerinde, standardize edilmemiş katsayılar ile bulguların daha doğru anlaşılacağı konusunda Kim ve Mueller'in (1976) ve Hayes'in (2013: 184-193) tavsiyeleri dikkate alınmış ve standardize edilmemiş katsayılar sunulmuştur.

Verilerin parametrik testlere uygunluğunu kontrol etmek için Field'ın (2005: 88) önerdiği yöntem kullanılmıştır. Çarpıklık (skewness) ve basıklık (kurtosis) değerleri standart hataya bölünerek z değerleri hesaplanmış ve Tablo 1'de sunulmuştur. \%95 güven düzeyinde mutlak $\mathrm{z}$ değeri 1,96'dan büyük olduğu durumda verilerde çarpıklık veya basıklık olmadığı hipotezi reddedilmektedir. Bu çerçevede güç motivasyonu, başarı motivasyonu, korkulu bağlanma ve bireysel değerler değişkenlerinde çarpıklık veya basıklık söz konusu değildir. Normatif değerler ve dünyevi değerler verilerinin basık olmadığı fakat çarpık olduğu sonucuna ulaşılmıştır. Bu sebeple bulgularda yer alan değişkenler arasında korelasyonlar hesaplanırken (Tablo 1) ilgili değişkenlerin (normatif değerler ve dünyevi değerler) olduğu analizlerde parametrik olmayan Spearman katsayısı verilmiştir. Alt gruplarda gerçekleştirilen korelasyon testlerinde ise (Tablo 2 ve Tablo 3) veri sayısı düşük olduğu için tüm korelasyon hesaplamalarında Spearman katsayısı kullanılmıştır. Düzenleyici etkinin araştırıldığı sonraki analizlerde ise parametrik olmayan testlerin yerine tavsiye edilen bootstrap prosedürü (DiCiccio ve Efron, 1996; Grunberg, 2001; Hayes ve Preacher, 2013: 36-38) kullanılmıştır.

\subsection{Bulgular}

Değişkenlerin ortalamaları, standart sapmaları, basıklıkları, çarpıklıkları, değişkenler arası korelasyonlar ve değişkenlerin hesaplamalarında kullanılan maddelerin iç tutarlılıkları (Cronbach alfa) Tablo 1'de sunulmuştur.

Tablo 1. Değişkenlere İlişkin Temel İstatistikler ve Korelasyonlar

\begin{tabular}{lccccc} 
Değişkenler & $(1)$ & $(2)$ & (3) & (4) & (5) \\
\hline (1) Güç Motivasyonu & $\mathbf{( 0 . 7 6 4 )}$ & & & & \\
(2) Başarı Motivasyonu & 0.220 & $\mathbf{( 0 . 7 2 5 )}$ & & & \\
(3) Korkulu Bağlanma & -0.118 & -0.168 & $\mathbf{( 0 . 6 7 8 )}$ & & \\
(4) Normatif Değerler & 0.223 & 0.185 & -0.005 & $\mathbf{( 0 . 6 0 7 )}$ & \\
(5) Bireysel Değerler & -0.037 & 0.130 & -0.099 & $0.404^{* *}$ & $\mathbf{( 0 . 6 4 6 )}$
\end{tabular}




\begin{tabular}{lcccccc} 
(6) Dünyevi Değerler & $0.256^{*}$ & $0.267^{*}$ & -0.037 & $0.533^{* *}$ & $0.308^{* *}$ & (0.615) \\
\hline Ortalama & 4.83 & 5.67 & 3.92 & 6.09 & 5.63 & 6.15 \\
Standart Sapma & 1.22 & 0.95 & 1.24 & 0.92 & 1.00 & 1.17 \\
Skewness/SE & $-0.51 / 0.28$ & $-0.53 / 0.28$ & $-0.45 / 0.28$ & $-1.06 / 0.28$ & $-0.51 / 0.28$ & $-1.33 / 0.28$ \\
Kurtosis/SE & $-0.36 / 0.56$ & $-0.61 / 0.56$ & $-0.67 / 0.56$ & $1.04 / 0.56$ & $-0.17 / 0.56$ & $0.54 / 0.56$ \\
\hline${ }^{*} \mathrm{p}<0.05 .{ }^{* *} \mathrm{p}<0.01 . \mathrm{N}=73$ & & & & & &
\end{tabular}

Not: Korelasyon katsayıları Pearson yöntemi ile hesaplanmıştır. Normatif değerler ve dünyevi değerler normal dağılım göstermediği için ilgili değişkenlerin yer aldığı korelasyon analizlerinde ise katsayılar Spearman yöntemi ile hesaplanmıştır. Diyagonalde yer alan koyu işaretlenmiş güvenilirlik bulguları Cronbach Alfa değerleridir.

Tablo 1'in diyagonalinde sunulan boyutlara ilişkin Cronbach alfa değerleri 0,6 ile 0,8 arasında değişmektedir. Bu aralıkta ölçüm araçlarının ve verilerin oldukça güvenilir olduğu söylenebilir (Kayış, 2010). Verilerin çarpıklık ve basıklık durumlarına ilişkin değerlendirmeler ve değişkenlerin durumuna göre hangi analizlerin kullanıldığı bir önceki Veri Analizi başlığı altında açıklanmıştır.

Yanıtlar 7'li Likert seçeneği toplandığı ve 1 ila 7 arasında kodlandığg için orta değer 4'tür. Korkulu bağlanma dişındaki tüm değişkenlerde ortalamalar 4'ün üzerindedir. Korkulu bağlanma ise orta değer olan 4'e yakındır $(\mu=3,92)$. Temel motivasyon kaynakları arasında katılımcıların başarı motivasyonları $(\mu=5,67)$ güç motivasyonlarına $(\mu=4,83)$ göre daha yüksektir $(\mathrm{t}=5,24, \mathrm{p}<0,01)$. Başarı motivasyonlarının bu kadar yüksek olması katılımcıların tamamının girişimci adayı olması, yani ciddi ve cesaret isteyen bir hedeflerinin olması ile açıklanabilir. Çalışma değerleri arasında normatif değerler ile bireysel değerler normal dağılım göstermediği için parametrik olmayan Wilcoxon işaretli sıralar testi ile çalışma değerlerinin alt boyutları karşılaştırılmıştır. Dünyevi değerler $(\mu=6,15)$ ile normatif değerler $(\mu=6,09)$ arasında anlamlı fark olmadığ $(t=1,09, p>0,05)$, bireysel değerlerin $(\mu=5,63)$ diğerlerine göre daha düşük olduğu ( $\left.t_{\text {normatif-bireysel }}=3,56, t_{\text {dünyevi-bireysel }}=3,27, p<0,01\right)$ sonucuna ulaşılmıştır.

Dünyevi değerler güç motivasyonu $(r=0,26, p<0,05)$ ve başarı motivasyonu $(r=0,27, p<0,05)$ ile düşük düzeyde bir ilişki göstermektedir. Çalışma değerleri arasında normatif değerler ile dünyevi değerler arasındaki ilişki orta düzeydedir $(\mathrm{r}=0,53, \mathrm{p}<0,01)$. Bireysel değerlerin normatif değerlerle $(r=0,40, p<0,05)$ ve dünyevi değerlerle $(r=0,31, p<0,01)$ ilişkisi bu ilişkiye göre biraz daha düşüktür.

\subsubsection{Başarı Motivasyonunun Normatif Çalışma Değerlerine Etkisi}

Araştırmanın hipotezleri bağlamında başarı motivasyonu ile çalışma değerleri arasındaki ilişkiler öncelikle hedef türleri alt gruplarında incelenmiştir. Katılımcılar içsel hedefli dışsal hedefli olarak iki gruba ayrılmış ve her bir alt grup için değişkenler arası korelasyonlar Tablo 2'de karşılaştırmalı olarak verilmiştir. 
Tablo 2. Hedef Türleri Alt Gruplarında Değişkenler Arası Korelasyonlar

Değişkenler

(1)

(2)

(3)

(4)

(5)

\begin{tabular}{|c|c|c|c|c|c|c|c|c|c|c|}
\hline Hedef Türleri & İH & $\mathrm{DH}$ & İH & $\mathrm{DH}$ & İH & DH & İH & DH & İH & $\mathrm{DH}$ \\
\hline \multicolumn{11}{|l|}{ (1) Güç Motivasyonu } \\
\hline (2) Başarı Motivasyonu & $0.36^{*}$ & 0.02 & & & & & & & & \\
\hline (3) Korkulu Băglanma & 0.01 & -0.30 & -0.25 & -0.35 & & & & & & \\
\hline (4) Normatif Değerler & 0.29 & 0.08 & $0.41^{* *}$ & -0.03 & 0.12 & -0.12 & & & & \\
\hline (5) Bireysel Değerler & -0.10 & -0.11 & 0.29 & -0.10 & 0.09 & -0.18 & $0.44^{* *}$ & $0.37^{*}$ & & \\
\hline (6) Dünyevi Değerler & 0.25 & 0.06 & $0.33^{*}$ & 0.20 & 0.14 & -0.31 & $0.47^{* *}$ & $0.66^{* *}$ & 0.26 & 0.31 \\
\hline
\end{tabular}

Akışı bozmamak için Tablo 2'deki korelasyonların tamamının değerlendirmesi burada yapılmayacaktır. İlerleyen bölümlerde Diğer İlişkiler başlığı altında korelasyon bulguları ayrıca değerlendirilecektir. Burada öncelikle araştırma sorusu bağlamında başarı motivasyonunun normatif değerlerle ilişkisindeki farka dikkat edilmelidir. İçsel hedefli olanlarda başarı motivasyonu ile normatif değerler arasında orta düzeyde bir ilişki varken $(\mathrm{r}=0,41, \mathrm{p}<0,01)$ dışsal hedefli olanlarda herhangi bir ilişki söz konusu değildir $(\mathrm{r}=-0,03$, $\mathrm{p}>0,05)$. Bu farklılık $\mathrm{H}_{1}$ : "Girişimci adaylarının başarı motivasyonlarının normatif çalışma değerlerine etkisini hedef türleri düzenler." hipotezinin test edilmesinin yerinde olduğunu göstermektedir. Hipotez testi için düzenleyici etki analizi gerçekleştirilmiştir. Analiz sonuçları Tablo 3 'te sunulmuştur.

Tablo 3. Başarı Motivasyonunun Normatif Değerlere Etkisinde Hedef Türlerinin Düzenleyici Rolü

\begin{tabular}{lcccccc}
\hline Bağımsız Değişken & $\boldsymbol{B}$ & $\boldsymbol{S E}$ & $\boldsymbol{t}$ & $\boldsymbol{p}$ & $\boldsymbol{L} \boldsymbol{L C I}$ & $\boldsymbol{U} \boldsymbol{C} \boldsymbol{I}$ \\
\hline \multicolumn{1}{c}{$R^{2}=0.12}$, & $F(3.66)$ & $=3.09, p<0.05 . \Delta R^{2}$ & $=0.07, F(1.66)=4.48, p<0.05$ & \\
Sabit & 6.13 & 0.11 & 54.95 & $<0.001$ & 5.90 & 6.35 \\
Başar1 Motivasyonu & 0.45 & 0.15 & 3.01 & 0.004 & 0.15 & 0.74 \\
Hedef Türleri & 0.04 & 0.21 & 0.20 & 0.842 & -0.38 & 0.46 \\
Başar1 Mot. x Hedef Tür. & -0.47 & 0.22 & -2.12 & 0.038 & -0.92 & -0.03 \\
\hline & $\boldsymbol{E f f e c t}$ & $\boldsymbol{S E}$ & $\boldsymbol{t}$ & $\boldsymbol{p}$ & $\boldsymbol{L L C I}$ & $\boldsymbol{U} \boldsymbol{C \boldsymbol { I }}$ \\
\hline
\end{tabular}

Farklı hedeflere sahip olanlarda başarı motivasyonunun normatif değerlere etkisi

$\begin{array}{lcccccc}\text { İçsel Hedefliler } & 0.45 & 0.15 & 3.01 & 0.004 & 0.15 & 0.75 \\ \text { Dişsal Hedefliler } & -0.02 & 0.17 & -0.14 & 0.890 & -0.35 & 0.31\end{array}$

Not: $\mathrm{LL}=$ alt limit; $\mathrm{CI}=95 \%$ güven aralığı; $\mathrm{UL}=$ üst limit.

Yanlılık hatasından arındırılmış 5000 örneklem bootstrap metodu kullanıldı. Regresyon katsayıları standardize edilmedi. Başarı motivasyonu analiz öncesi ortalamaya göre standardize edildi (mean centered). İçsel hedefliler 0, dişsal hedefliler 1 olarak kodlandi.

Düzenleyici etki bulgularından bahsetmeden önce tabloda dikkat çekici bir bulguyu tartışmak yerinde olacaktır. Model içerisinde başarı motivasyonunun normatif değerlere direkt etkisinde orta düzey pozitif bir etki gözlemlenmektedir $(\beta=0.45, \mathrm{SE}=0.15, \mathrm{t}=3.01, \mathrm{p}<0.05)$. Bu durum kafa karıştırıcı gelebilir. Normalde başarı motivasyonunun normatif değerler üzerinde direkt 
bir etkisi beklenmemektedir. Diğer değişkenlerle birlikte (özellikle etkileşim değişkeni olan başarı mot. X hedef tür.) modele alındığı için durum bu şekilde ortaya çıkmıştır. Başarı motivasyonunun tek başına 5000 bootstrap ile normatif değerler üzerindeki etkisi regresyon analizi ile test edilmiş ve anlamlı bir etkiye rastlanmamıştır $(\beta=0.22, \mathrm{SE}=0.13, \mathrm{p}>0.05)$.

Düzenleyici etkiyi ifade eden hedef türleri ile başarı motivasyonu etkileşiminin normatif değerlere etkisi anlamlıdır $(\beta=-0.47, \mathrm{SE}=0.22, \mathrm{t}=-2.12, \mathrm{p}<0.05)$. Yani hedef türlerinin düzenleyici etkisi söz konusudur. $\mathrm{H}_{1}$ : “Girişimci adaylarının başarı motivasyonlarının normatif çalışma değerlerine etkisini hedef türleri düzenler.” hipotezi kabul edilmiştir. Tablo 3'ün alt bölümünde hedef türlerine göre başarı motivasyonunun normatif değerlere etkisi incelenmiştir. İçsel hedeflilerde başarı motivasyonun normatif değerlere etkisi pozitif ve anlamlıdır (etki katsayısı $=0.45, \mathrm{p}<0.01$ ). Dışsal hedeflilerde ise herhangi bir etki söz konusu değildir (etki katsayısı=-0.02, p>0.05). Hedef türlerine göre başarı motivasyonunun normatif değerlere etkisindeki değişim Şekil 3 'te gösterilmiştir.

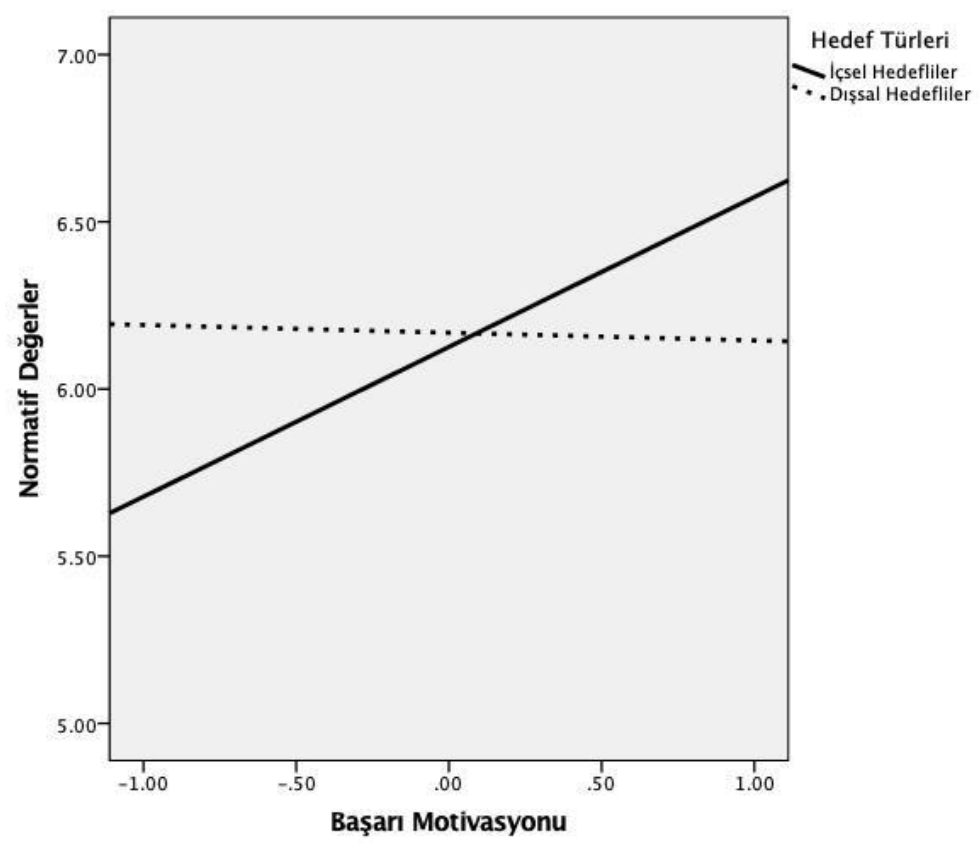

Şekil 3. Hedef Türlerine Göre Başarı Motivasyonunun Normatif Değerlere Etkisi

Bulgular Şekil 3'te daha net anlaşılmaktadır. İçsel hedeflilerde çizgi yukarıya doğru eğimlidir. Başarı motivasyonu yükseldikçe normatif değerler de yükselmektedir. Dışsal hedeflilerde ise çizginin eğimi neredeyse yoktur ve başarı motivasyonunun normatif değerlere bir etkisi gözlemlenmemektedir. 


\subsubsection{Güç Motivasyonunun Normatif Çalışma Değerlerine Etkisi}

Güç motivasyon ile çalışma değerleri arasındaki ilişkiler korkulu bağlanma alt gruplarında incelenmiştir. Katılımcıların korkulu bağlanma düzeylerinin medyanı orta nokta kabul edilmiş ve orta noktanın üzerindeki katılımcıların korkulu bağlanma düzeyleri yüksek, altındaki katılımcıların düşük kabul edilmiştir. Buradaki amaç hipotez testi değildir. İlişkiler hakkında fikir edinmektir. Hipotez testi için korkulu bağlanma değişkeni sürekli değişken olarak analize dahil edilecektir. Korelasyon analizinde katılımcılar korkulu bağlanma düzeylerine göre iki gruba ayrılmış ve her bir alt grup için değişkenler arası korelasyonlar Tablo 4'te karşılaştırmalı olarak verilmiştir.

Tablo 4. Korkulu Bağlanma Alt Gruplarında Değişkenler Arası Korelasyonlar

\begin{tabular}{lcccccccc} 
Değişkenler & \multicolumn{2}{c}{ (1) } & \multicolumn{2}{c}{ (2) } & \multicolumn{2}{c}{ (3) } & \multicolumn{2}{c}{ (4) } \\
\hline Korkulu Bağlanma & Düşük & Yüksek & Düşük & Yüksek & Düşük & Yüksek & Düşük & Yüksek \\
\hline (1) Güç Motivasyonu & & & & & & & & \\
(2) Başarı Motivasyonu & 0.14 & 0.23 & & & & & & \\
(3) Normatif Değerler & $0.34^{*}$ & 0.11 & $0.36^{*}$ & 0.06 & & & & \\
(4) Bireysel Değerler & 0.07 & -0.25 & 0.01 & 0.03 & 0.11 & $0.64^{* *}$ & & \\
(5) Dünyevi Değerler & 0.20 & $0.33^{*}$ & 0.31 & 0.18 & $0.50^{* *}$ & $0.59^{* *}$ & $0.37^{*}$ & 0.25 \\
\hline
\end{tabular}

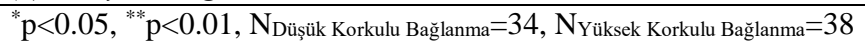

Not: Korelasyon katsayıları Spearman yöntemi ile hesaplanmıştır.

Tablo 4'teki korelasyon bulgularının genel değerlendirmesi akışı bozmamak için sonraki bölümde yapılacaktır. Burada güç motivasyonunun normatif değerlerle ilişkisindeki farka dikkat edilmelidir. Korkulu bağlanma düzeyi düşük olanlarda güç motivasyonu ile normatif değerler arasında anlamlı bir ilişki varken $(r=0.34, p<0,01)$ korkulu bağlanma düzeyi yüksek olanlarda anlamlı bir ilişki söz konusu değildir $(\mathrm{r}=0,11, \mathrm{p}>0,05)$. Bu farklılık $\mathrm{H}_{2}$ : "Girişimci adaylarının güç motivasyonlarının normatif çalışma değerlerine etkisini korkulu bağlanma düzenler." hipotezinin test edilmesine gerekçe oluşturmaktadır. Hipotez testi için gerçekleştirilen düzenleyici etki analizinin sonuçları Tablo 5'te sunulmuştur.

Tablo 5. Güç Motivasyonunun Normatif Değerlere Etkisinde Korkulu Bağlanmanın Düzenleyici Rolü

\begin{tabular}{|c|c|c|c|c|c|c|}
\hline Bağımsız Değişken & $B$ & $S E$ & $t$ & $p$ & $L L C I$ & $U L C I$ \\
\hline \multicolumn{7}{|c|}{$R^{2}=0.14, F(3.68)=2.78, p<0.05, \Delta R^{2}=0.07, F(1.68)=3.87, p=0.053$} \\
\hline Sabit & 6.06 & 0.11 & 54.43 & $<0.001$ & 5.84 & 6.29 \\
\hline Güç Motivasyonu & -0.01 & 0.10 & -0.13 & 0.898 & -0.22 & 0.19 \\
\hline Korkulu Bağlanma & 0.22 & 0.09 & 2.46 & 0.017 & 0.04 & 0.41 \\
\hline \multirow[t]{2}{*}{ Güç Mot. x Korkulu Bağ. } & -0.18 & 0.09 & -1.97 & 0.053 & -0.36 & 0.00 \\
\hline & Effect & $S E$ & $t$ & $p$ & $L L C I$ & ULCI \\
\hline
\end{tabular}

Farklı korkulu bağlanma düzeylerinde güç motivasyonunun normatif değer düzeyine etkisi

\begin{tabular}{lllllll}
-1 ss & 0.45 & 0.16 & 2.72 & 0.008 & 0.12 & 0.78 \\
$M$ & 0.22 & 0.09 & 2.46 & 0.017 & 0.04 & 0.41 \\
+1 ss & -0.00 & 0.12 & -0.00 & 0.999 & -0.25 & 0.25 \\
\hline
\end{tabular}

Not: $L L=$ alt limit; $C I=95 \%$ güven aralığl; $U L=\ddot{u} s t$ limit. 
Yanlılık hatasından arındırılmış 5000 örneklem bootstrap metodu kullanıldı. Regresyon katsayıları standardize edilmedi. Güç motivasyonu ve korkulu bağlanma değişkenleri analiz öncesi ortalamaya göre standardize edildi (mean centered).

Düzenleyici etkiyi gösteren korkulu bağlanma ile güç motivasyonu etkileşiminin normatif değerlere etkisinin anlamlılık düzeyi, araştırmalarda genel kabul gören 0,05 değerinin çok az üzerindedir $(\beta=-0.18, \mathrm{SE}=0.09, \mathrm{t}=-2.12, \mathrm{p}=0.053)$. Bu araştırmada örneklem oldukça küçük olduğu için sınırda olan bu değer anlamlı kabul edilmiştir. Yani korkulu bağlanmanın düzenleyici etkisi söz konusudur. $\mathrm{H}_{2}$ : "Girişimci adaylarının güç motivasyonlarının normatif çalışma değerlerine etkisini korkulu bağlanma düzenler." hipotezi kabul edilmiştir. Tablo 5 'in alt bölümünde korkulu bağlanma düzeylerine göre güç motivasyonunun normatif değerlere etkisi incelenmiştir. Korkulu bağlanma düzeyi düşük olanlarda güç motivasyonun normatif değerlere etkisi pozitif ve anlamlıdır (etki katsayısı $=0.45, \mathrm{p}<0.01$ ). Korkulu bağlanma düzeyi orta seviyede olanlarda güç motivasyonun normatif değerlere etkisi nispeten düşük fakat yine pozitif ve anlamlıdır (etki katsayısı=0.22, p<0.05). Korkulu bağlanma düzeyi yüksek olanlarda ise güç motivasyonun normatif değerlere etkisi yoktur (etki katsayıs1=-0.00, $\mathrm{p}>0.05$ ). Korkulu bağlanma düzeylerine göre güç motivasyonunun normatif değerlere etkisindeki değişim Şekil 4'te gösterilmiştir.

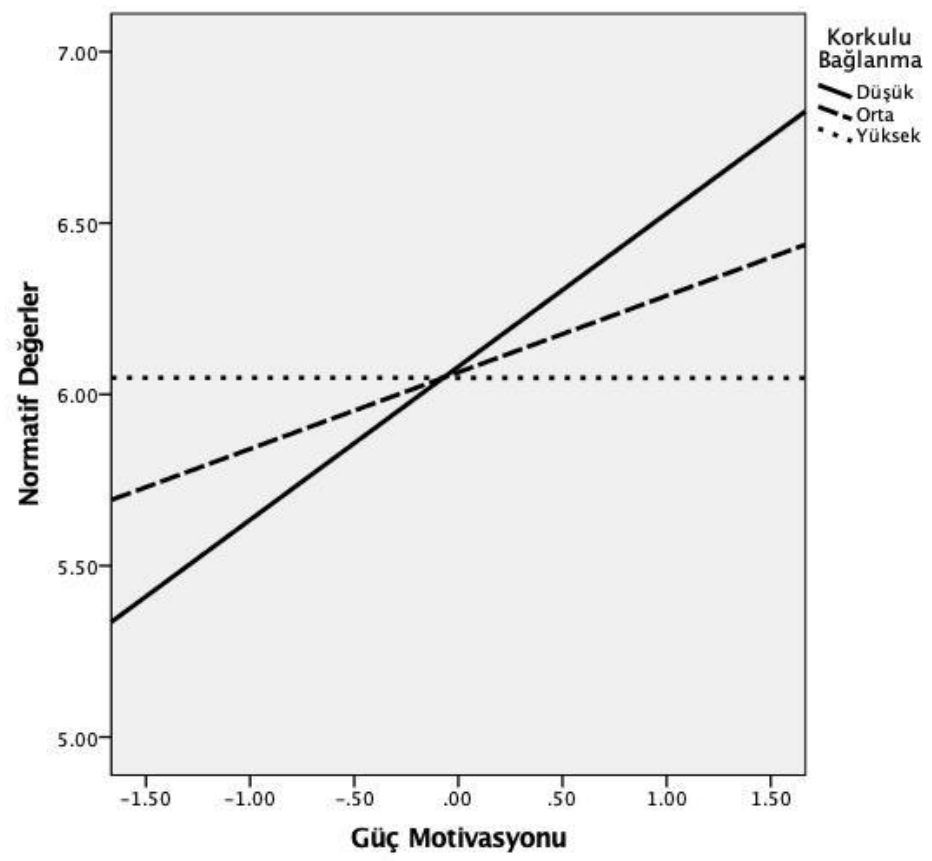

Şekil 4. Korkulu Bağlanma Düzeylerine Göre Güç Motivasyonunun Normatif Değerlere Etkisi

Korkulu bağlanma düzeyi düşük olanlardan yüksek olanlara doğru gittikçe çizgilerin yukarıya doğru olan eğimi azalmakta ve kaybolmaktadır. Korkulu bağlanma düzeyi düşük olanlarda güç motivasyonunun normatif değerlerle ilişkisi oldukça yüksektir. Korkulu bağlanma düzeyi yüksek olanlarda ise güç motivasyonunun normatif değerlere bir etkisi gözlemlenmemektedir. 


\subsubsection{Diğer İlişkiler}

Buraya kadar olan kısımda araştırma sorusu çerçevesinde hipotez test sonuçları sunulmuştur. Araştırma sorusunun kapsamı dışında kalsa da sonraki araştırmalara rehberlik etmesi açısından çarpıcı diğer bazı bulgulara bu başlık altında yer verilecektir. Tablo 2 ve Tablo 4'te sunulan korelasyon bulgularında çalışma değerlerinin diğer boyutları da yer almaktadır. $\mathrm{Bu}$ çalışmanın amacı normatif değerlere odaklanmak, güç ve başarı motivasyonlarının normatif değerlere etkisini düzenleyici değişkenler bağlamında incelemektir. Bununla beraber Tablo 2 ve Tablo 4'teki sonuçlar, araştırma kapsamında yer alan düzenleyici değişkenlerin, güç ve başarı motivasyonlarının bireysel ve dünyevi çalışma değerlerine etkisinde de düzenleyici etki gösterebileceği fikrini doğurmuştur.

Öncelikle Tablo 2'ye bakılırsa; içsel hedeflilerde başarı motivasyonunun dünyevi değerlerle ilişkisi pozitif ve anlamlıdır $(\mathrm{r}=0.33, \mathrm{p}<0.05)$. Dışsal hedeflilerde ise ilişki anlamlı düzeyde değildir $(\mathrm{r}=0.20, \mathrm{p}>0.05)$. Her iki grupta da başarı motivasyonunun bireysel değerlerle ilişkisi anlamlı düzeyde değildir $(p>0.05)$ fakat içsel hedeflilerdeki korelasyon katsayısı $(r=0,29)$ ile dışsal hedeflilerdeki korelasyon katsayısı $(\mathrm{r}=-0.10)$ epey uzak gözükmektedir. Güç motivasyonunun çalışma değerleri ile ilişkilerinde de benzer bir durum söz konusudur. Güç motivasyonunun hiçbir grupta hiçbir çalışma değeri ile ilişkisi anlamlı değildir $(p>0.05)$. Bununla beraber normatif değerlerle ilişkisinde içsel hedeflilerle $(\mathrm{r}=0,29)$ dişsal hedeflilerin $(r=0.08)$ korelasyon katsayılarında gözlenen fark ve dünyevi değerlerle ilişkisinde içsel hedeflilerle $(\mathrm{r}=0.25)$ dışsal hedeflilerin $(\mathrm{r}=0.06)$ korelasyon katsayılarında gözlenen fark dikkat çekicidir. Bu ilişkilerde de düzenleyici etki olabilir düşüncesiyle bütün bu gözlenen farklıklar \%95 güven düzeyinde düzenleyici etki analizi ile test edilmiş fakat anlamlı bir bulguya rastlanmamıştır $(\mathrm{p}<0.05)$. Yine de bu araştırmada örneklem sayısı çok yüksek olmadığ 1 için ilerleyen araştırmalarda daha geniş örneklemlerde bu ilişkilerin tekrar test edilmesinin isabetli olacağı fikri oluşmuştur. Girişimci adaylarının hedef türleri, güç ve başarı motivasyonlarının diğer çalışma değerlerine (bireysel ve dünyevi) etkisini de düzenliyor olabilir.

Tablo 4'te de benzer bir durum söz konusudur. Korkulu bağlanma düzeyine göre ayrılan gruplarda korelasyon katsayılarındaki farklılıklar dikkat çekicidir. Korkulu bağlanma düzeyi düşük olanlarda baş̧arı motivasyonunun bireysel değerlerle ilişkisi pozitif ve anlamlı olsa da $(\mathrm{r}=0.36, \mathrm{p}<0.05)$ dişsal hedeflilerde ilişki anlamlı düzeyde değildir $(\mathrm{r}=0.06, \mathrm{p}>0.05)$. Korelasyon katsayısının anlamlı düzeyde olduğu bir başka sonuç korkulu bağlanma düzeyi yüksek olanlarda güç motivasyonunun dünyevi değerlerle ilişkisindedir $(\mathrm{r}=0.33, \mathrm{p}<0.05)$. Korkulu bağlanma düzeyi düşük olanlarda anlamlı bir ilişki söz konusu değildir $(\mathrm{r}=0.20$, $\mathrm{p}<0.05)$. Son olarak güç motivasyonunun bireysel değerler ile ilişkisi dikkat çekmektedir. Her iki grupta da anlamlı ilişki söz konusu değildir ( $\mathrm{p}>0.05$ ) fakat korkulu bağlanma düzeyi düşük olanlardaki korelasyon katsayısı $(\mathrm{r}=0.07)$ korkulu bağlanma düzeyi yüksek olanlarınkinden $(\mathrm{r}=-0.25)$ epey uzak gözükmektedir. Bütün bu gözlenen farklıklar \%95 güven düzeyinde düzenleyici etki analizi ile test edilmiş ve sadece tek bir anlamlı bulguya rastlanmıştır. $\mathrm{O}$ da güç motivasyonu ile bireysel değerlerin ilişkisindedir. Bahsi geçen analizin sonuçları Tablo 6 'da sunulmuştur. 
Tablo 6. Güç Motivasyonunun Bireysel Değerlere Etkisinde Korkulu Bağlanmanın Düzenleyici Rolü

\begin{tabular}{|c|c|c|c|c|c|c|}
\hline Bağımsız Değişken & $B$ & $S E$ & $t$ & $p$ & $L L C I$ & ULCI \\
\hline \multicolumn{7}{|c|}{$R^{2}=0.10, F(3.68)=2.46, p=0.07, \Delta R^{2}=0.09, F(1.68)=5.57, p<0.05$} \\
\hline Sabit & 5.60 & 0.12 & 45.34 & $<0.001$ & 5.35 & 5.85 \\
\hline Güç Motivasyonu & -0.09 & 0.11 & -0.84 & 0.404 & -0.30 & 0.12 \\
\hline Korkulu Bağlanma & -0.02 & 010 & -0.18 & 0.861 & -0.21 & 0.18 \\
\hline \multirow[t]{2}{*}{ Güç Mot. x Korkulu Bağ. } & -0.23 & 0.10 & -2.36 & 0.021 & -0.42 & -0.04 \\
\hline & Effect & $S E$ & $t$ & $p$ & $L L C I$ & $U L C I$ \\
\hline \multicolumn{7}{|c|}{ Farklı korkulu bağlanma düzeylerinde güç motivasyonunun bireysel değer düzeyine etkisi } \\
\hline$-1 s s$ & 0.26 & 0.18 & 1.47 & 0.146 & -0.09 & 0.62 \\
\hline$M$ & -0.02 & 0.10 & -0.18 & 0.861 & -0.21 & 0.18 \\
\hline$+1 s s$ & -0.30 & 0.13 & -2.38 & 0.020 & -0.55 & -0.05 \\
\hline
\end{tabular}

Not: $\mathrm{LL}=$ alt limit; $\mathrm{CI}=95 \%$ güven aralığı; $\mathrm{UL}=$ üst limit.

Yanlılık hatasından arındırılmış 5000 örneklem bootstrap metodu kullanıldı. Regresyon katsayıları standardize edilmedi. Güç motivasyonu ve korkulu bağlanma değişkenleri analiz öncesi ortalamaya göre standardize edildi (mean centered).

Bağımlı değişkenin bireysel çalışma değerleri olduğu analizde korkulu bağlanma ile güç motivasyonu etkileşiminin bağımlı değişkene etkisi anlamlıdır $(\beta=-0.23, \mathrm{SE}=0.10, \mathrm{t}=-2.36$, $\mathrm{p}<0.05)$. Yani girişimci adaylarının güç motivasyonlarının bireysel çalışma değerlerine etkisini korkulu bağlanmanın düzenlediği söylenebilir. Tablo 6'nın alt bölümünde korkulu bağlanma düzeylerine göre güç motivasyonunun bireysel değerlere etkisi incelenmiştir. Korkulu bağlanma düzeyi düşük olanlarda güç motivasyonun bireysel değerlere etkisi pozitif fakat anlamlı düzeyde değildir (etki katsayısı=0.26, p>0.05). Korkulu bağlanma düzeyi orta seviyede olanlarda güç motivasyonun bireysel değerlere etkisi neredeyse hiç yoktur (etki katsayısı $=-0.02, \mathrm{p}<0.05)$. Korkulu bağlanma düzeyi yüksek olanlarda ise güç motivasyonun bireysel değerlere etkisi negatif ve anlamlıdır (etki katsayısı=-0.30, p<0.05). Korkulu bağlanma düzeylerine göre güç motivasyonunun bireysel değerlere etkisindeki değişim Şekil 5 'te gösterilmiştir.

Korkulu bağlanma düzeyi düşük olanlardan yüksek olanlara doğru gittikçe çizgilerin eğimi pozitiften negatife doğru değişmektedir. Korkulu bağlanma düzeyi düşük olanlarda güç motivasyonunun bireysel değerlerle ilişkisi pozitif eğimli, yüksek olanlarda negatif eğimlidir. Korkulu bağlanma düzeyine göre güç motivasyonu ile bireysel değerlerin ilişkisinin değiştiği görselden de anlaşılmaktadır.

$\mathrm{Bu}$ araştırma güç ve başarı motivasyonlarının normatif çalışma değerleri ile ilişkisi bağlamında kurgulanmıştır. Bununla beraber analizler ışığında anlaşılmıştır ki, güç ve başarı motivasyonlarının diğer çalışma değerleri ile ilişkileri de mercek altına alınmalıdır. Hedef türlerine ve korkulu bağlanma düzeylerine göre ilişkiler düzenleniyorsa, neden böyle bir düzenleyici etkinin olduğu ilgili literatür ışığında incelenmelidir. 


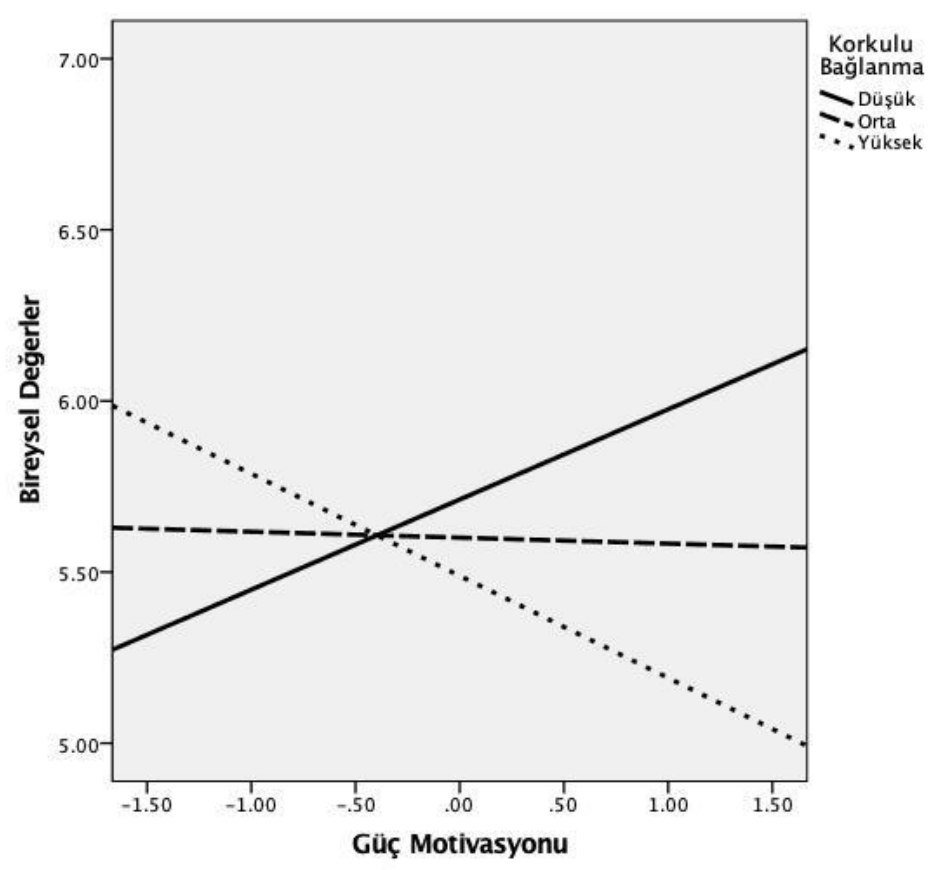

Şekil 5. Korkulu Bağlanma Düzeylerine Göre Güç Motivasyonunun Bireysel Değerlere Etkisi

\section{SONUÇ VE TARTIŞMA}

İş yapmanın veya girişimciliğin sebepleri, sonuçları veya ürettiği değerlerinden bahsedebilmek için (girişimci) birey öncelikle "çalışma" faaliyetini gerçekleştirmelidir. Çünkü "çalışma" faaliyeti, bireyin girişimcilik veya iş yapma vasıtasıyla değer üretebilmesi açısından temel unsurdur. Bireylerin çalışma sürecinde ve neticesinde farklı değerlere odaklandıkları söylenebilir. Literatürde girişimciliğin finansal ve kişisel ödüller alma firsatından yararlanma ile ilgili olduğu yönünde görüşler bulunmaktadır. Hatta girişimciler tarafından belirtilen söz konusu kişisel ödüller arasında bağımsızlık ve özgürlüğe yer verilmektedir (Boyd ve Gumperd, 1983: 46). Bunun yanında girişimcilerin sahip oldukları değerlerin bir yaşam tarzı olarak ele alınabileceği yönünde görüşler bulunmaktadır. Bireylerin öncelikli olarak yollarını tanımlamaları ve belirledikleri hedeflere ulaşma konusunda firsatları değerlendirmeleri gerekmektedir. Girişimciliğin sonuçları ya içsel veya dişsal olacaktır. Dışsal çıktılar performans ile ölçülen parasal yahut diğer somut ödülleri içermektedir. Girişimciler için içsel ödüller genellikle kendi patronu olmanın, kendi hayatını daha iyi yönlendirmenin ve girişimin başarısı için esas sorumluluğa sahip olmanın memnuniyetini merkeze alan başarılardır. Tüm sonuçların, iş sahibi bireylerde belirli düzeyde algılanan değeri bulunmaktadır. Dolayısıyla bu bireylerin kendi sonuçlarına değer verme sistemleri olacaktır (Kuratko, 1997: 26). Halbuki girişimcilerin/iş yapanların çalışma faaliyetleri neticesinde ortaya çıkması gereken değerlerin; sadece ekonomik kazanç, içsel/dışsal ödüller veya farklı bireysel kazanımlarla sınırlı olmaması gerektiği söylenebilir. Çünkü çalışma faaliyetinin bireye birçok getirisi bulunmaktadır. Belki de ilk olarak akla gelen çalışmanın ekonomik getirisidir. Fakat ekonomik getirisinin öncelikli amaç olmaktan çıkması durumunda 
dahi bireyin çalışma niyetini muhafaza etmesi önemlidir. Çünkü çalışmanın ekonomik getiri dışında bireye; toplumda yer almak, sosyal hayata katkıda bulunmak ve insanlarla ilişsiler inşa etme imkânı sunması söz konusudur (Turgut ve Tevrüz, 2003: 58). Bu nedenle girişimci adaylarının çalışma değerlerini etkileyen unsurların bireysel ve ekonomik değerler dişındaki değerlerle tanımlanması önemlidir. Çünkü bir girişimcinin sadece kendi önemsediği değil toplum tarafından önemsenen hangi değerlere sahip olabileceğinin tespit edilmesi, nitelikli bir çalışma yaşamının oluşturulmasına katkı sağlayacaktır.

Normatif değerler; topluma katkıda bulunmak, dini görevini yapmak, sakınmak ve düzenini kurmak başlıklarıyla tanımlanmaktadır. Topluma katkıda bulunmak; topluma hizmet etmeyi, sosyal ve ekonomik refaha katkıda sağlamayı amaç olarak belirlemektir. Dini görevini yapmak; Allah'ın rızasını almayı, ahireti kazanmayı ve dini görevini yapmış olmayı istemektir. Sakınmak; kötü yola sapmaktan, yabancılaşmaktan kendini korumayı ve yararlı, huzurlu ve sağlıklı olmayı hedeflemektir. Düzenini kurmak; kendine bir yuva, bir iş kurarak düzenli bir hayat sürmeye ulaşma istediğidir (Tevrüz, 2017: 25). Normatif değerlerin içeriğine bakıldığında, en dikkat çekici nokta; ağırlıklı olarak bireyin "çevresine katkı sağlamayı amaç edinme" eğiliminde olmasıdır.

Literatürde farklı meslek gruplarının farklı çalışma değerlerini ürettiği ifade edilmektedir. Çalışma değerleri bağlamında esnaf grubunun, memur ve profesyonel meslek sahipleriyle kıyaslandığında, çalışmanın normatif boyutunda en yüksek ortalamaya sahip oldukları ortaya koyulmuştur. Yani normatif işlevi olan tüm amaçlar, esnaf grubu için önemlidir. Bu bağlamda esnaf grubunun, topluma katkıda bulunma, dini görevini yapma, sakınma ve düzenini kurma amaçlarını önemli gören topluluk olarak Türk toplumunun geleneksel değerlerine sahip çıkan meslek grubu olduğu ifade edilmektedir (Turgut ve Tevrüz, 2003). KOSGEB'in düzenlediği girişimcilik eğitimini alan bireylerin daha çok esnaf adayı oldukları bilinmektedir. Genel bir bakış açısı olarak meslekler bağlamında esnaf grubunun normatif değerlere verdikleri önem derecesinin yüksek olması beklenebilir. Nitekim bu çalışmada da içsel hedefli, kendisi ve çevresi ile ilgili olumsuz algısı düşük olan güç ve başarı odaklı girişimci adaylarının normatif değer üretme potansiyeli taşıdığ 1 tespit edilmiştir.

Çalışmada, hangi girişimci adaylarının değer üretmeye odaklanacağını tahmin etmeye yönelik değişkenlere odaklanılmıştır. Tevrüz ve arkadaşlarının (2010) çalışma değerleri üzerinde geliştirdikleri ölçekte "değer üretme" ile ilgili çalışma değerleri "normatif değerler" başlığ1 altında ele alınmıştır. Etkili bir girişimciliğin tahmininde önemli olan başarı ve güç motivasyonlarının normatif değerler üzerindeki etkisi düzenleyici değişkenler ile incelenmiştir. Ulaşılan iki temel sonuç şunlardır:

- İçsel hedefli girişimci adaylarında başarı motivasyonu normatif değerleri pozitif etkilemektedir. Dışsal hedefli girişimci adaylarında böyle bir etki söz konusu değildir.

- Korkulu bağlanma (olumsuz çevre ve benlik algısı) düzeyi düşük olan girişimci adaylarında güç motivasyonu normatif değerleri pozitif etkilemektedir. Girişimci adaylarının korkulu bağlanma düzeyi yükseldikçe bu etki kaybolmaktadır.

Özetle şöyle bir sonuca varılabilir: İçsel hedefli olan, olumlu çevre ve benlik algısına sahip olan girişimci adaylarında, başarılı girişimcilik için gerekli olan yüksek güç ve başarı motivasyonu, değer üretme potansiyelini de beraberinde taşıyabilecektir. Araştırmanın iş dünyası, girişimcilerin eğitimi ve toplumla ilgili en önemli sonucu budur. 
Olumsuz çevre algısına sahip (kaçınmacı bağlanan) girişimci adaylarında yüksek başarı motivasyonunun normatif değer üretmediği bir başka araştırmada ortaya konulmuştur. Çevrelerine yönelik algıları olumsuz olan bireylerde başarı motivasyonu yükseldikçe statü, prestij, para, güç, gelecek güvencesi, ekonomik özgürlük gibi dünyevi değerlere daha çok ön plana çıkmaktadır. Bulundukları topluma ve yaşadıkları çevreye güven duymayan başarı odaklı girişimci adayları, daha bağımsız ve maddi anlamda güvenli bir yaşam istemektedirler. Topluma katkıdan ziyade; prestij, otorite, kariyer ve maddi varlık elde ederek toplumdan saygı görmeyi amaç edinmektedirler (Özkul ve Antalyalı, 2017). Bu çalışmada da güç motivasyonu yüksek bireylerin olumsuz benlik ve çevre algısına sahip olduklarında normatif değer üretmeyecekleri ortaya konulmuştur. Her iki çalışma bağlamında şu söylenebilir: Başarı ve güç isteği, bireyin kendisine ve çevresine güvendiği takdirde değer üretmesini sağlayacaktır.

Araştırma sorusunun kapsamı dışında kalsa da sonraki araştırmalar için fikir verebilecek birtakım analizler gerçekleştirilmiştir. Bu çalışmada normatif değerlere odaklanılmış olsa da güç ve başarı motivasyonlarının diğer çalışma değerlerine etkisinde de hedef türlerinin, çevre ve benlik algısının düzenleyici etkisi olabileceği fikri edinilmiştir. Daha geniş bir örneklemde çalışılması durumunda daha belirgin sonuçlara ulaşılabilir. Ayrıca kullanılan ölçüm araçları gözden geçirilebilir. Örneğin bağlanma stili için dört boyutlu ortagonal yapılı ölçek yerine iki boyutlu (kaygı ve kaçınma) ölçekler kullanılabilir. Ya da hedef türlerini belirlemek için Likert tipi ölçekler denenebilir. Çalışma, konunun incelenmeye ve derinleşmeye değer olduğunu ortaya koymaktadır. $\mathrm{Bu}$ çalışmadan elde edilen kısa vadeli pratik sonuç; değer üretme potansiyeli olan girişimci adaylarının öngörülebilmesi sayesinde, girişimci adaylarını destekleyen ve değer üretme kaygısı olan odakların, tercihlerine uygun girişimci adaylarını seçebilmesine katkı sağlayacaktır. Uzun vadeli pratik sonuç ise; değer üretme potansiyeli olan girişimci bir neslin yetiştirilmesinde odaklanılması gereken başlıkların bir kısmını ortaya koyarak, erken gelişim döneminden itibaren çocukların eğitimine katkı sağlayacak bulgular sunmaktadır.

\section{KAYNAKÇA}

AINSWORTH, M. D. S., BLEHAR, M. C., WATERS, E., \& WALL, S. (1978). Patterns of Attachment: A Psychological Study of the Strange Situation, Hillsdale, NJ: Lawrence Erlbaum Associates.

AKSOY, B., KOÇANCI, M., \& NAMAL, M. K. (2019). "Girişimimcilik Motivasyonu: Uygulamalı Girişimcilik Eğitimi Katılımcıları Örneği”, Yönetim ve Ekonomi: Celal Bayar Üniversitesi İktisadi ve İdari Bilimler Fakültesi Dergisi, 26(1): 109-129.

ANTALYALI, Ö. L. \& BOLAT, Ö. (2017). “Öğrenilmiş İhtiyaçlar Bağlamında Temel Motivasyon Kaynakları (TMK) Ölçeğinin Geliştirilmesi, Güvenilirlik ve Geçerlik Analizi”, AİBÜ Sosyal Bilimler Enstitüsü Dergisi, 17(1): 83-114.

BARTHOLOMEW, K., \& HOROWITZ, L. M. (1991). “Attachment Styles Among Young Adults: A Test of a Four-Category Model", Journal of Personality and Social Psychology, 61(2): 226-244.

BOWLBY, J. (1973). Attachment and Loss: Vol. 2. Separation: Anxiety and Anger, New York: Basic Books. 
BOYD, D. P., \& GUMPERT, D. E. (1983). “Coping with Entrepreneurial Stress”, Harvard Business Review, 61(2): 44-64.

BRENNAN, K. A., CLARK, C. L., \& SHAVER, P. R. (1998). "Self Report of Measurement of Adult Attachment: An Integrative Overview”, J. A. Simpson \& W. S. Rholes (Eds.), Attachment Theory and Close Relationships (ss.46-76), New York: Guilford.

BULL, I., WILLARD, \& G. E. (1993). "Towards a Theory of Entrepreneurship, Journal of Business Venturing”, 8(3): 183-195.

CACIOPPO, J. T., \& PETTY, R. E. (1982). “The Need For Cognition, Journal of Personality and Social Psychology”, 42(1): 116-131.

CARVER, C. S. (1997). “Adult Attachment and Personality: Converging Evidence and New Measure, Personality and Social Psychology Bulletin”, 23(8): 865-883.

DAVIS, F. D., BAGOZZI, R. P., \& WARSHAW, P. R. (1992). "Extrinsic and Intrinsic Motivation to Use Computers in the Workplace, Journal of Applied Social Psychology", 22(14): 1111-1132.

DICICCIO T. J., \& EFRON, B. (1996). “Bootstrap Confidence Intervals”, Statistical Science, 11(3): 189-228.

FIELD, A. (2005). "Discovering Statistics Using SPSS", 2nd Edition, Sage Publications, London, UK.

GEORGE, J. M., JONES, G. R., \& SHARBROUGH, W. C. (2012). "Understanding and Managing Organizational Behavior”, 6th Edition, New Jersey: Prentice Hall.

GRIFFIN, D. W., \& BARTHOLOMEW, K. (1994) "The Metaphysics of Measurement: The Case of Adult Attachment", K. Bartholomew \& D. Perlman (Eds.), Attachment Process in Adulthood: Advances in Personal Relationships (Vol. 5: 17-52), London: Jessica Kingsley Publishers.

GRUNBERG, D. (2001). "Bootstrapping and the Problem of Testing Quantitative Theoretical Hypotheses", Philosophy of Science, 10: 143-150.

GÜNAYDIN, G., SELÇUK, E., SÜMER, N., \& UYSAL, A. (2005). "Ebeveyn ve Arkadaşlara Bağlanma Envanteri Kısa Formunun Psikometrik Açıdan Değerlendirilmesi”, Türk Psikoloji Yazıları, 8(16): 13-23.

HARPAZ, I., \& SNIR, R. (2003). "Workaholism: Its Definition and Nature", Human Relations, 56(3), 291-319.

HAYES, A. F. (2013). Introduction to Mediation, Moderation, and Conditional Process Analysis: A Regression-based Approach, Guilford Press.

HAYES, A. F., \& PREACHER, K. J. (2013). "Conditional Process Modeling: Using Structural Equation Modeling to Examine Contingent Causal Processes", G. R. Hancock \& R. O. Mueller (Eds.), Structural Equation Modeling: A Second Course, 2nd Edition, Charlotte, NC: Information Age Publishing.

HAZAN, C., \& SHAVER, P. R. (1987). "Romantic Love Conceptualized as An Attachment Process, Journal of Personality and Social Psychology”, 52(3): 511-524. 
HAZAN, C., \& SHAVER, P. R. (1990). "Love and Work: An Attachment-theoretical Perspective, Journal of Personality and Social Psychology", 59(2): 270-280.

HUCZYNSKI, A. A., \& BUCHANAN, P. D. A. (2013). Organizational Behaviour (8th Edition), New York: Pearson.

İNANÇOĞLU, E. (2002). “Çalışma Değerlerinin Örgütsel Değişime Dirence Etkisi”, 10. Ulusal Yönetim Organizasyon Kongresi Bildiri Kitabı, Akdeniz Üniversitesi, Antalya, 23-25 Mayıs 2002: 146-160.

KASSER, T., \& RYAN, R. M. (1996). "Further Examining The American Dream: Differential Correlates of Intrinsic and Extrinsic Goals", Personality and Social Psychology Bulletin, 22: 280-287.

KAYIŞ, A. (2010). “Güvenilirlik Analizi”, içinde Ş. Kalaycı (Der.), SPSS Uygulamalı Çok Değişkenli İstatistik Teknikleri, 5. Baskı, Ankara: Asil Yayın Dağıtım.

KIM, J. O., \& MUELLER, C. W. (1976). "Standardized and Unstandardized Coefficients in Causal Analysis: An Expository Note", Sociological Methods \& Research, 4(4): 423438.

KINICKI, A., \& FUTAGE, M. (2018). "Organizational Behaviour: A Practical, ProblemSolving Approach", 2th Edition, New York: McGraw-Hill Education.

KURATKO, D. F., HORNSBY, J. S., \& NAFFZIGER, D. W. (1997). "An Examination of Owner's Goals in Sustaining Entrepreneurship", Journal of Small Business Management, 35(1): 24-34.

LANGTON, N., \& ROBBİNS, S. P. (2006). "Fundamentals of Organizational Behaviour", Third Canadian Edition, Toronto: Pearson.

LOW, M.B., \& MACMILLAN, I.C. (1988). "Entrepreneurship: Past Research and Future Challenges". Journal of Management, 14(2): 139-161.

MIKULINCER, M., \& SHAVER, P. R. (2016). “Attachment in Adulthood, Second Edition”, New York London, The Guildford Press.

ÖZKUL A. S., \& ANTALYALI, Ö. L. (2017). "Girişimcilikte Başarı Motivasyonunun Çalışma Değerlerine Etkisinde Olumsuz Çevre Algısının Düzenleyici Rolü”, 25. Ulusal Yönetim ve Organizasyon Kongresi, 25-27 Mayıs 2017, Başkent Üniversitesi, Ankara: 203-212.

ÖZKUL A. S., ANTALYALI Ö. L., \& ŞATIRER H. (2018). "Temel Motivasyon Kaynakları ile Çalışma Değerleri İlişkisi: KOSGEB Girişimcilik Eğitimi Alan Bireyler Üzerine Bir Araştırma", III. INES International Education and Social Science Congress (ESS2018), Alanya/Antalya, Türkiye, 28 Nisan-01 Mayıs 2018: 591.

ÖZKUL, M. (1997). Çalışma Sosyolojisi - İşgücünün Sosyolojik Özellikleri, Isparta.

ROBBINS, S. P., \& JUDGE, T. A. (2017). Örgütsel Davranış, 14. Basımdan Çeviri, Çeviri Ed.: Erdem, İ., Ankara: Nobel. 
RYAN, R. M., \& DECI, E. L. (2000). "Self-Determination Theory and the Facilitation of Intrinsic Motivation, Social Development, and Well-Being", American Psychologist: 68-78.

SCHMUCK, P., KASSER, T., \& RYAN, R. M. (2000). "Instrinsic and Extrinsic Goals: Their Structure and Relationship to Well-Being in German and U.S. College Students", Social Indicators Research, 50: 225-241.

SELÇUK, E., GÜNAYDIN, G., SÜMER, N., \& UYSAL, A. (2005). "Yetişkin Bağlanma Boyutları İçin Yeni Bir Ölçüm: Yakın İlişkilerde Yaşantılar Envanteri-II'nin Türk Örnekleminde Psikometrik Açıdan Değerlendirilmesi”, Türk Psikoloji Yazıları, 8(16): 1-11.

SÜMER, N. (2006). Ergenlikte Ebeveyn Tutum ve Davranışlarının Kaygısındaki Rolü, 11. Ergen Konuşma Metni, Hacettepe Üniversitesi.

SÜMER, N., \& GÜNGÖR, D. (1999a). "Çocuk Yetiştirme Stillerinin Bağlanma Stilleri, Benlik Değerlendirmeleri ve Yakın İlişkiler Üzerindeki Etkisi”, Türk Psikoloji Dergisi, 14(44): 35-58.

SÜMER, N., \& GÜNGÖR, D. (1999b). "Yetişkin Bağlanma Stillerinin Ölçeklerinin Türk Örneklemi Üzerinde Psikometrik Değerlendirmesi ve Kültürlerarası Bir Karşılaştırma", Türk Psikoloji Dergisi, 14(43): 71-106.

TEVRÜZ, S., \& TURGUT, T. (2004). "Çalışma Amaçlarının Tespiti ve Çalışma Amaçları Testinin Geliştirilmesi”, Öneri Dergisi, 6(22): 33-44.

TEVRÜZ, S., TURGUT, T., \& ÇİNKO, M. (2010). Bir Merakın Peşinde: Amaç’tan Başarı'ya, 1. Baskı, İstanbul, Beta.

THOMPSON, J. L., \& MARTIN, F. (2005). Strategic Management: Awareness and Change, 5th Edition, Hong Kong: South-Western.

TURGUT, T. (1996). İş Adamlarının Yaşam ve Çalışma Değerleri, Yüksek Lisans Tezi, Marmara Üniversitesi, Sosyal Bilimler Enstitüsü, İstanbul.

TURGUT, T. (2017). Çalışma Değerleri, içinde T. Turgut \& M. Çinko (Eds.), Değerli İnsana Değerli Çalışmalar Yaşam ve Çalışma Değerleri Üzerine Araştırmalar (ss.21-49), 1. Bask1, İstanbul: Beta.

WINTER, D. G. (1973). The Power Motive, New York: Free Press. 